\title{
Recorregut de recerca geològica i mineralògica per les comarques de la Garrotxa (Alta Garrotxa) i del Ripollès: des de Castellfollit de la Roca a Oix, Beget, Rocabruna i a Camprodon
}

Josep Maria Mata-Perelló

Joaquim Sanz Balagué

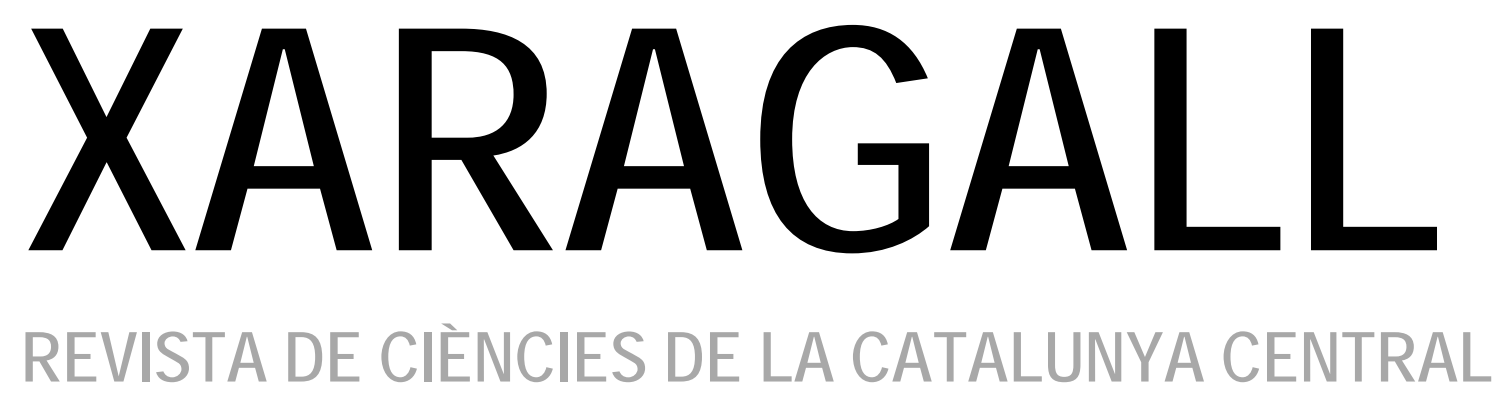

ก. 6

JUNY 2014 


\title{
RECORREGUT DE RECERCA GEOLÒGICA I MINERALÒGICA PER LES COMARQUES DE LA GARROTXA (ALTA GARROTXA) I DEL RIPOLLĖS: DES DE CASTELLFOLLIT DE LA ROCA A OIX, BEGET, ROCABRUNA I A CAMPRODON
}

\author{
Josep Maria Mata-Perelló \\ Museu de geologia Valentí Masachs, Escola Politècnica Superior d'Enginyeria de Manresa \\ (EPSEM), Universitat Politècnica de Catalunya · BarcelonaTech (UPC), 08272 Manresa, Spain
}

\author{
Joaquim Sanz Balagué \\ Departament d'Enginyeria Minera i Recursos Naturals (EMRN), Escola Politècnica Superior \\ d'Enginyeria de Manresa (EPSEM), Universitat Politècnica de Catalunya . BarcelonaTech \\ (UPC), 08272 Manresa, Spain
}

Paraules clau: Zona volcànica de la Garrotxa; Materials volcànics; Materials mesozoics; Materials paleozoics; Mines

\section{Resum}

Itinerari realitzat l'1 de juny del 2013. El recorregut del present itinerari, es desenvoluparà íntegrament pel Sistema Pirinenc; i més concretament ho farà per diversos sectors del mateix. Així, s'iniciarà a la denominada Zona Sudpirenenca, per on es faran les primeres aturades, entre Castellfollit de la Roca i Oix. En aquest tram, haurem trobat afloraments cenozoics fonamentalment.

Després, el recorregut transitarà entre afloraments mesozoics del Cretàcic, dintre del denominat Prepìrineu Meridional. Això succeirà fonamentalment entre les poblacions d'Oix i de Beget. Aquests darrers materials s'inclouen dintre del Mantell del Cadí, en la seva major part; tot i així, també haurem trobat afloraments mesozoics, que s'inclouen dintre del Mantell del Castell de Bac Grillera. I finalment, ja prop del darrer poble esmentat, començarem a trobar afloraments paleozoic, especialment del Carbonífer i del Devonià. Aquests materials també pertanyen al Mantell del Cadí. Aquests materials els trobarem fonamentalment entre Rocabruna, la Mina de les Ferreres i Camprodon. Al Nord d'aquests, es troba I'Encavalcament de Ribes de Fresser, que no arribarem a trobar. Aquest es situa entre el Mantell del Cadí (al Sud) i el Mantell del Canigó (al Nord, del nostre recorregut).

Per d'altra banda, també cal dir que aquest recorregut s'efectuarà, íntegrament per les comarques pirinenques. Així, discorrerà quasi totalment per la comarca de la Garrotxa (i més concretament de l'Alta Garrotxa), però fent un recorregut final per la comarca del Ripollès, per on finalitzarà el recorregut de l'Itinerari. 


\section{Objectius fonamentals}

A través d'aquest itinerari geològic-mineralògic, s'intentaran d'aconseguir els següents objectius, d'acord amb el recorregut de l'itinerari:

1. Observació dels materials cenozoics, que trobarem pels voltants de Castellfollit de la Roca, en el primer tram del recorregut, quasi en arribar a les immediacions de la població d'Oix. Aquests materials pertanyen en la seva major part a l'Eocè, situant-se dintre del Subpirineu

2. Dintre del context anterior: observació dels materials volcànics que trobarem pels voltants de Castellfollit de la Roca. Aquests materials, situats al Nord de l'Encavalcament Sudpirinenc, es situen dintre de la Zona Volcànica de la Garrotxa.

3. Observació dels materials mesozoics (del Cretàcic i especialment del Garumnià), que formen part del Mantell del Castell de Bac Grillera, que trobarem per les immediacions de la població d'Oix

4. Observació dels materials paleozoics (fonamentalment de l'Ordovicià i també del Devonià, del Carbonífer i del Pèrmic), i del mesozoics (del Garumnià, més exclusivament), que formen part del Mantell del Cadí, pels indrets per on discorre el present itinerari, pels voltants de Rocabruna. I també pels voltants de Camprodon,

5. Interpretació a distancia de la Falla de Camprodon-Ribes de Freser. Aquesta es troba al Nord del recorregut.

6. Estudi de diverses mineralitzacions situades al llarg del recorregut de l'itinerari, com les següents, com les mineralitzacions de $\mathrm{Ba}-\mathrm{Cu}$, de rebliment de cavitats d'origen càrstic, les quals es troben (entre altres indrets), al paratge de Rocabruna (del terme de Beget), actualment dintre de la comarca del Ripollès, i antigament del de la Garrotxa.

7. Estudi i observació de les explotacions relacionades amb els afloraments de les mineralitzacions acabades d'esmentar.

8. Observació del les tasques de restauració espontània, desenvolupades sobre les explotacions mineres.

9. Observació dels diferents indrets, i dels LIG (Llocs de Interès Geològic) i dels LIPM (Llocs d'Interès del Patrimoni Miner) que anirem trobant al llarg del recorregut de l'itinerari.

\section{Antecedents}

Cal dir que en relació amb l'existència d'antecedents bibliogràfics, en relació amb el present itinerari, hi ha alguns antecedents nostres, tot i que molt parcials. Es tracta de: Mata-Perelló, (1996, 1997a, 1997b, 1998a, 1998b i 2007), coincidents en unes petites parts amb el present. També cal fer esment d'un altre itinerari, en part nostre: Mata-Perelló i Sanz (1993), igualment coincident en alguns trams. Tot i així, aquest itinerari, en la seva major part es totalment inèdit.

Per d'altra banda, en canvi, farem esment de diversos treballs, de caràcter geològic general $\mathrm{i}$ regional, com són els següents: Guimerà et altri (1992), i Riba et altri (1976). Tanmateix, i pel que fa a les monografies regionals, farem esment dels treballs: IGME (1991). Al mateix temps, farem esment del treball de BRGM (1936); així com del de SGE (1992). 
I, pel que fa a l'estudi de les mineralitzacions situades dintre de l'àrea per la qual discorre I'itinerari, farem esment d'un altre treball nostre, concretament del Mata-Perelló (1991). També farem esment d'un treball relacionat amb un itinerari proper ja esmentat més amunt: MataPerelló (1998).

Tots aquests treballs, i d'altres, figuraran degudament relacionats per ordre alfabètic, i per data de publicació, dintre de l'apartat d'aquest treball dedicat a les referencies bibliogràfiques.

\section{Recorregut de l'itinerari}

El recorregut de l'itinerari, s'iniciarà per les immediacions de la població de Castellfollit de la Roca, per on es realitzaran les primeres aturades. Tot seguit, el recorregut es dirigirà cap a Oix, per on farem diverses aturades, dintre de la comarca de la Garrotxa.

Posteriorment, el recorregut es dirigirà cap a Beget i cap a Rocabruna, per on farem diverses aturades, després d'entrar a la comarca del Ripollès. Des del darrer poble es farà una fillola, per tal d'anar cap a les antigues Mines de Rocabruna.

Finalment, el recorregut continuarà per la comarca del Ripollès. Així, s'anirà cap a la població de Camprodon, per on finalitzarà el recorregut de l'itinerari, després de fer les dues darreres aturades.

\section{Advertiments previs}

Com en altres recorreguts de recerca geològica i mineralògica ..., si es disposa del temps suficient, poden efectuar-se passant per totes les parades i filloles. En cas contrari, recomanem prescindir de les anomenades parades - condicionals.

Cal dir també, que en aquest itinerari ens trobarem davant de tres trams de camins forestals en molt mal estat de conservació; per la qual cosa serà molt millor transitar a peu per ells. Aquest és el cas del camí que condueix des de les Ferreres a les immediacions del Coll de Vernadell, per tal d'anar a les Mines de Rocabruna.

I, finalment, en qualsevol cas, cal tenir sempre una cura molt especial de respecte a la natura, al llarg de tot el recorregut; de l'itinerari.

\section{Descripció de l'itinerari}

Com de costum, estructurarem el recorregut de l'itinerari en una sèrie de PARADES (o d'ESTACIONS), que tot seguit anirem veient. En cadascuna d'aquestes aturades farem un breu comentari (geològic o mineralògic, segons s'escaigue). Per d'altra banda, en cada cas indicarem, entre parèntesi, el full topogràfic on es troba l'aturada.

En aquest itinerari, utilitzarem dos tipus de cartografia. Per una banda els següents fulls de la Cartografía Militar de España (o del Instituto Geográfico y Catastral-IGC, a escala 1:50.000: 218 (dit de Molló), 256 (o de Ripoll) i 257 (dita també d'Olot). Totes les aturades i recorreguts 
del present itinerari, es trobaran situades almenys dintre d'un dels tres mapes anteriors. Així doncs, la relació general de les parades ordenades que constitueixen aquest itinerari, és la següent:

\subsection{Parada 1. INICI DE LA CARRETERA DE CASTELLFOLLIT DE LA ROCA A OIX (GIV - 5221), (terme municipal de Castellfollit de la Roca, comarca de la Garrotxa). (Full 257).}

El recorregut el podem iniciar pels voltants de Can Peric, molt prop de la cruïlla d'on surt la carretera GiV - 5221, la qual es dirigeix cap a la propera població d'Oix, situada també en aquesta comarca de las Garrotxa. Així, ara ens trobem molt prop del poble de Castellfollit de la Roca.

Ara ens trobem al bell mig de la Zona Volcànica de la Garrotxa, dintre del Sistema Transversal i també de I'anomenat Subpirineu, amb materials cenozoics de la Depressió Geològica de I'Ebre, on aquests es troba afectats per fractures transversals. Tanmateix, som molt a prop de la Falla Sudpirinenca, de I'Encavalcament de Vallfogona, la qual es troba al Sud de Castellfollit de la Roca.

Des d'aquest indret, és possible de veure una interessant superposició de colades basàltiques, sobre les que es troba situat el poble de Castellfollit de la Roca. També hi ha la possibilitat d'entrar al poble, i de recórrer-lo fins a l'extrem del cingle que formen les colades basàltiques. En aquest cas, l'observació es realitzaria des de dalt. (fotografia 1).

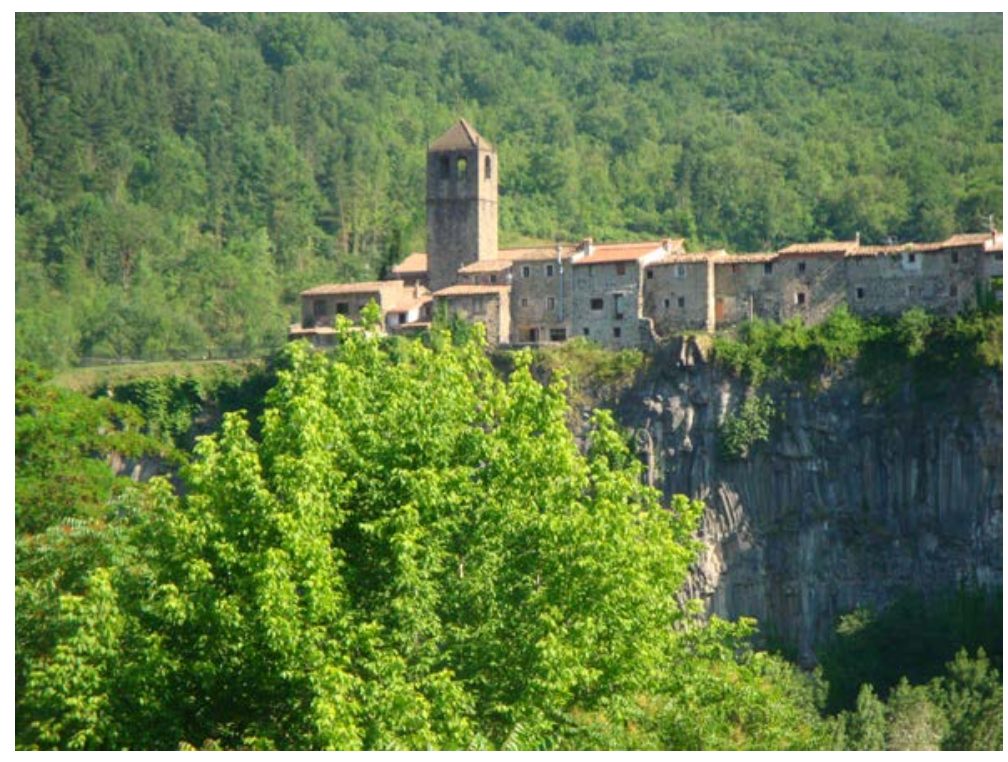

Fotografia 1. Columnata de basalts de Castellfollit de la Roca

\subsection{Parada 2 - CONDICIONAL. TERRASSA FLUVIAL DEL FLUVIÀ, Km 1 DE LA CARRETERA GIV - 5221, (terme municipal d'Oix i Montagut, comarca de la Garrotxa, Alta Garrotxa). (Full 257).}


Després de realitzar la parada anterior, cal agafar la carretera GiV - 5221, la qual es va dirigint cap al proper poble d'Oix. A poc més d’haver recorregut $1 \mathrm{Km}$, des de l'inici, i s'escau, podem fer una nova aturada.

En aquest recorregut, haurem trobat afloraments dels materials cenozoics, fonamentalment de I'Eocè. En bona part, aquests materials tenen tonalitats grisenques, essent de la formació Armàncies. Tot i així, en aquest indret hi ha un aflorament de la terrassa mitja del riu Fluvià.

\subsection{Parada 3. PEDRERA DELS GORGS, Km 4'4 DE LA CARRETERA GIV - 5221, (terme municipal d'Oix i Montagut, comarca de la Garrotxa, Alta Garrotxa). (Full 257).}

Després de fer l'aturada anterior, cal continuar cap al Nord, seguint sempre la carretera GiV 5221, la qual ens va apropant cap el poble d'Oix, trobant-nos ara al seu terme municipal. En arribar a les immediacions del $\mathrm{Km} \mathrm{4} 4$, farem una nova aturada, a poc més de 3’4 Km des de l'indret de l'aturada anterior.

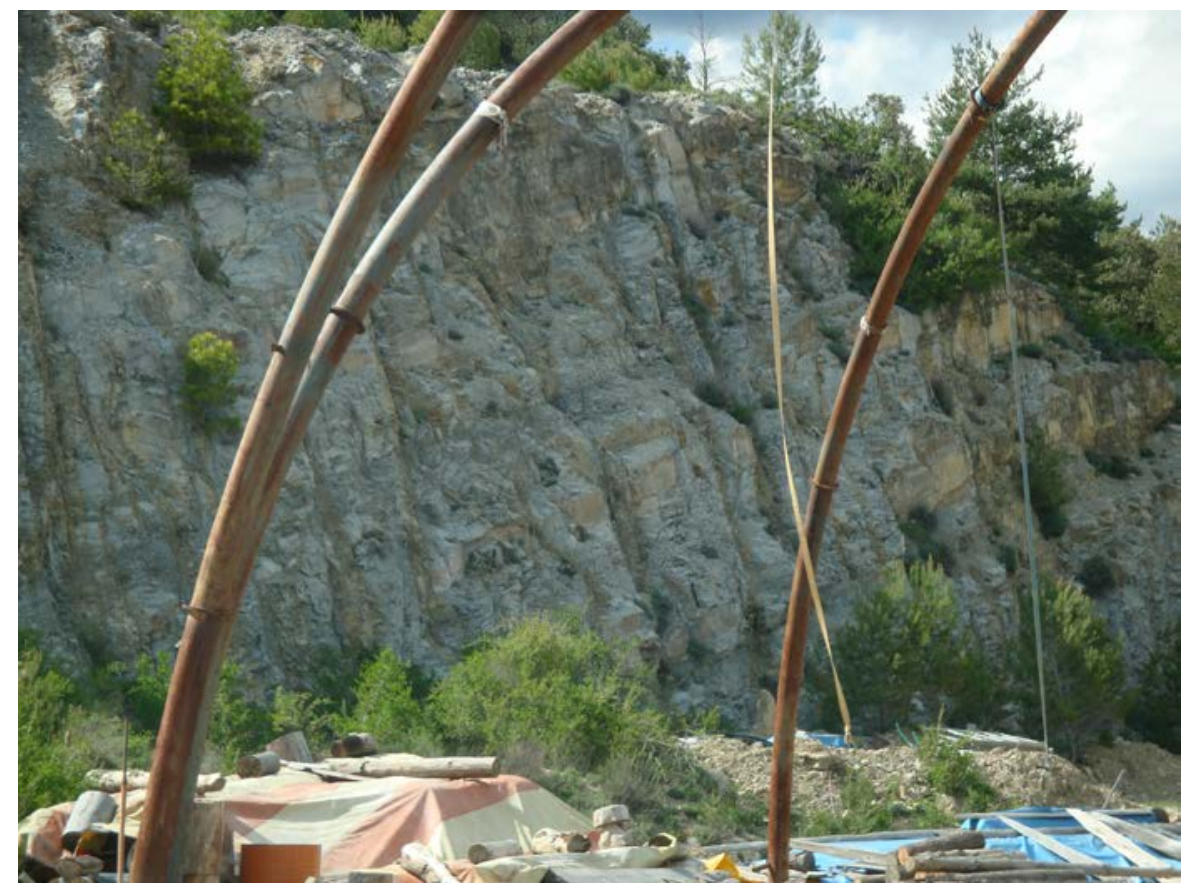

Fotografia 2. Pedrera de calcàries dels Gorgs. Terme d’Oix

En aquest recorregut, hem continuat trobant afloraments dels materials cenozoics (fonamentalment de l'Eocè, del Lutecià), els quals formen part de l'anomenat Subpirineu, on ens trobem situats. En aquest indret hi ha un aflorament de calcolutites i calcàries de la Formació Armàncies. En aquest indret, han estat explotats aquests materials carbonatats, en una antiga pedrera. (fotografía 2).

Cal remarcar que en torn a la pedrera, es troben les instal-lacions de tractament de les roques estretes. 


\subsection{Parada 4. IMMEDIACIONS DEL Km 8 DE LA CARRETERA GIV - 5221, (terme municipal d'Oix i Montagut, comarca de la Garrotxa, Alta Garrotxa). (Full 257).}

Després de realitzar la parada anterior, cal continuar anant cap a Oix, tot seguint sempre la carretera GiV - 5221. En arribar a les immediacions del Km 8, podem fer una nova aturada, a poc més de 3' $5 \mathrm{Km}$ de l'anteriorment realitzada.

En aquest recorregut, hem continuat trobant afloraments dels materials esmentats a les aturades anteriors. Així, hem vist nivells de calcolutites, calcàries i gresos de tonalitats generalment grisenques. Aquests materials son cenozoics, fonamentalment de l'Eocè (i més concretament del Lutecià). Aquests materials es troben situats dintre del Subpirineu, on ara continuem estant situats.

Aquests materials, a l'indret de a present aturada, es troben constituïts per gresos i calcolutites, trobant-se intensament plegats i replegats, en funció del grau de competència de les roques que formen part de l'aflorament. Així, a l'indret de l'aturada, es poden observar aquestes estructures. (fotografia 3).

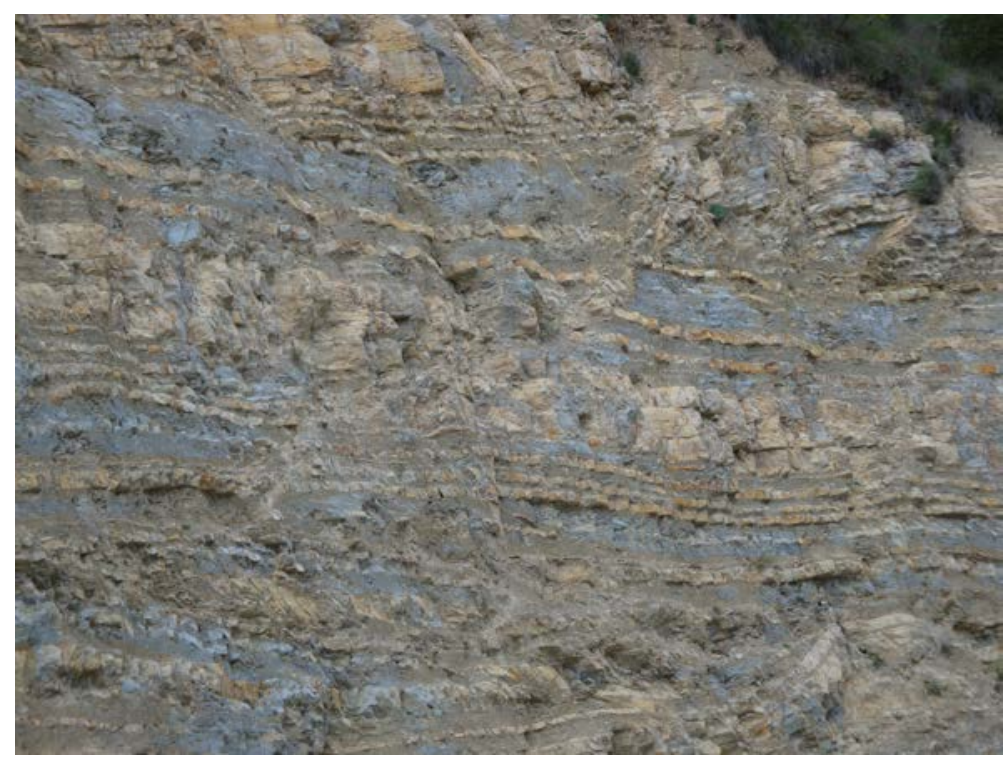

Fotografia 3. Pedrera de calcàries dels Gorgs. Terme d’Oix

\subsection{Parada 5. SORTIDA D'OIX CAP A BEGET, CARRETERA GIV - 5223, (terme municipal d'Oix i Montagut, comarca de la Garrotxa, Alta Garrotxa). (Full 257).}

Després de realitzar l'aturada anterior, cal continuar cap al proper poble d'Oix, tot seguint ara per la carretera GiV - 5223. Així, aviat arribarem al poble esmentat, des d'on ens caldrà continuar, ara cap a Beget. Poc després de començar aquest tram, a menys de $1 \mathrm{~km}$ d'Oix i a uns 4 de la parada anterior, efectuarem una nova aturada. 
En aquest tram, hem anat trobant inicialment els materials esmentats a les aturades anteriors. Aquests materials son també els que apareixen pels voltants d'Oix. Tanmateix en aquest indret es troben abundants sediments detrítics quaternaris, del diu d'Oix.

Per altra banda, anant ara cap a Beget i mirant cap a l'Este i cap a l'ENE, podem veure unes interessants estructures. Es tracta dels afloraments dels nivells carbonatats del Garumnià, tot formant part del Mantell del Castell de Bac Grillera, formant part de la Serra del Cucut. (fotografia 4).

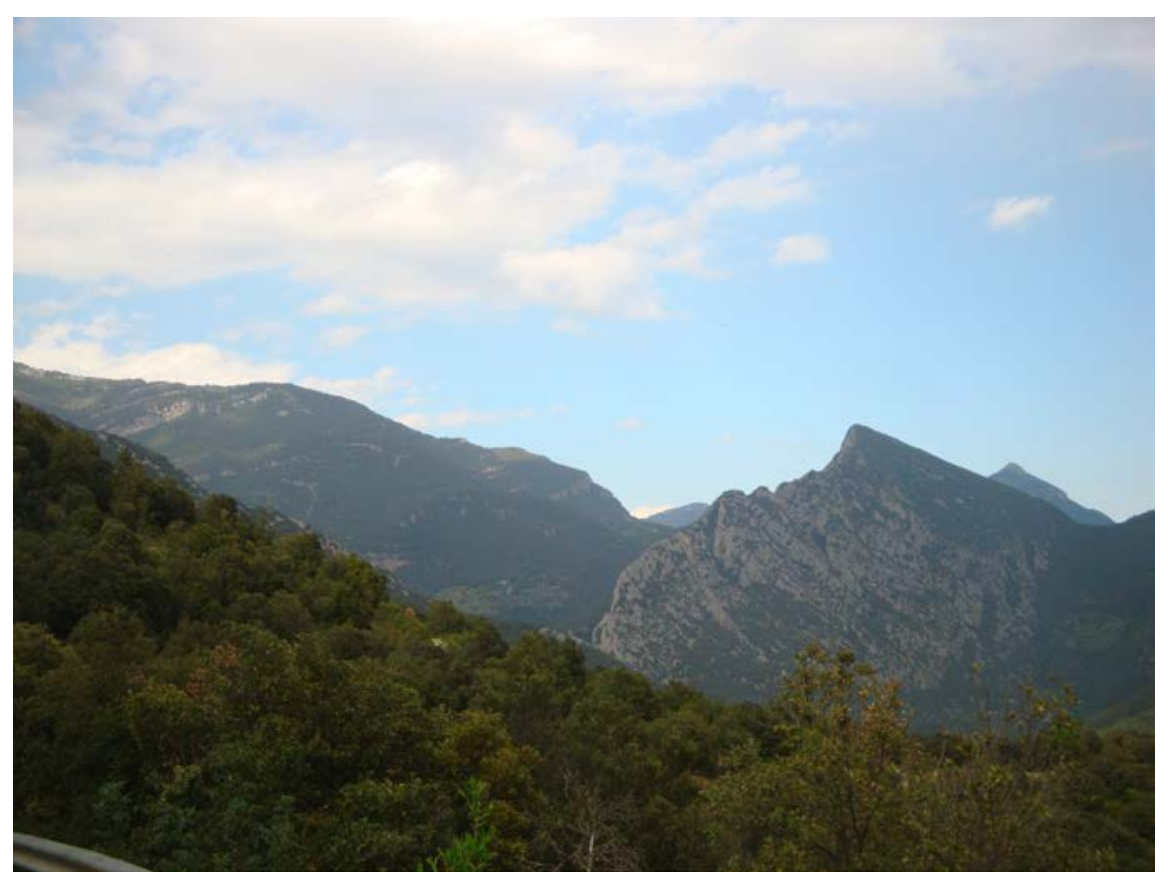

Fotografia 4. Serra del Cucut. Terme d’Oix

\subsection{Parada 6. CARRETERA D'OIX A BEGET, MONTMAJOR, GIV - 5223, (Beget, terme municipal de Camprodon, comarca del Ripollès, Alta Garrotxa; antigament del terme de Beget, de la comarca de la Garrotxa). (Full 257).}

Després de realitzar l'aturada anterior, cal continuar per la carretera local GiV - 5223, la qual es va dirigint cap al poble de Beget. Per aquesta carretera anirem ascendint, fent uns giravolts, situats al peu de la Serra de Bestrecà. Així, la carretera es va apropant al Coll de Bestrecà. Poc abans d'arribar-hi, ens caldrà fer4 una nova aturada, a uns $3 \mathrm{Km}$, aproximadament, de la parada anterior.

En aquest recorregut, haurem trobat afloraments de l'Eocè (fonamentalment del Cusià i del Lutecià). Aquests materials es troben constituïts per nivells de gresos, calcolutites i calcaries. Ocasionalment, també haurem trobat nivellets de conglomerats.

Més amunt, haurem trobat la part frontal del Mantell de Castell de Bac Guillera. Així, haurem trobat nivells calcolutítics de l'llerdià i després nivells carbonatats d'aquests materials, corresponents a la Formació Sagnari de I'llerdià. Per sobre nostre, a la Serra de Bestrecà, hi 
afloren nivells carbonatats del Garumnià. I més amunt materials granítics del Permià Carbonífer. Aquests materials formen part del Mantell del Cadí.

Per d'altra banda, des de l'indret on fem aquesta aturada, abans d'arribar al Coll de Bestrecà, mirant cap al SW, podem veure els relleus de Montmajor, al Sud de las vall del riu d'Oix. Aquests relleus de Montmajor, es troben constituïts per una repetició de l'estructura de la que acabem de parlar, referent a la Serra de Bestrecà, destacant els nivells carbonatats de les calcàries de I'llerdià i del Garumnià. Tanmateix, en dies clars, es pot veure una repetició de la sèrie, provocada per una fractura. (fotografia 5).

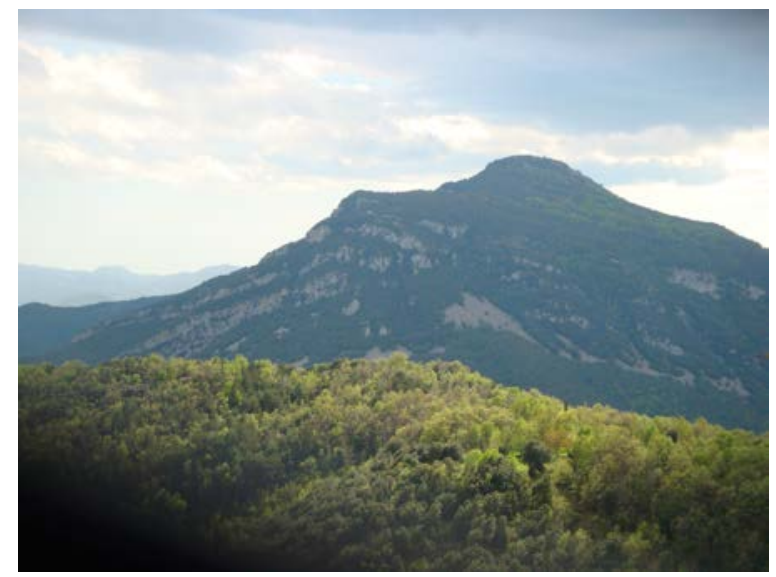

Fotografia 5. Montmajor. Terme d'Oix

Aquesta estructura de Montmajor, també forma part del Mantell del Castell de Bac Guillera, com la Serra de Bestrecà, de la que es troba separada per una sèrie de fractures de direcció NNW - SSE.

Per d'altra banda, al Nord de Montmajor (i al Sud de Sant Miquel de la Pera), es pot veure la vall molt encaixada del riu d'Oix, a ponent de la població del mateix nom. (fotografia 6).

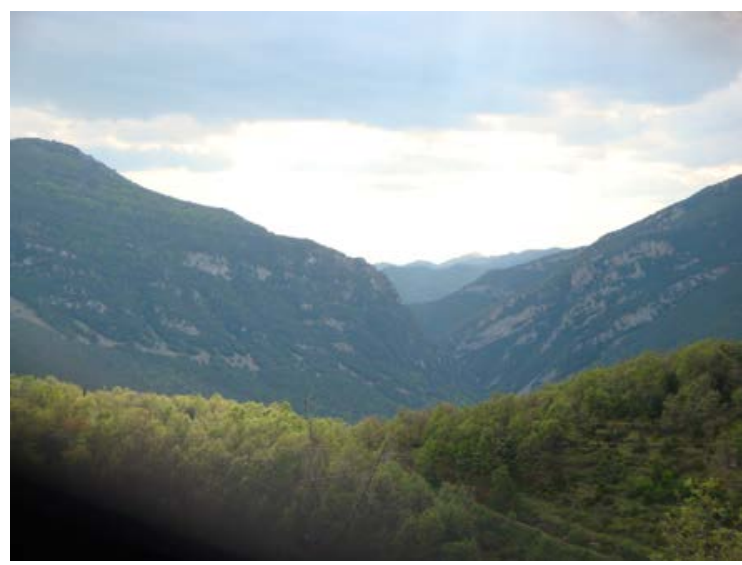

Fotografia 6. Vall del riu d’Oix. Terme d'Oix 


\subsection{Parada 7. CINGLERA DE BEGET, (Beget, terme municipal de Camprodon, comarca del Ripollès, Alta Garrotxa; antigament del terme de Beget, de la comarca de la Garrotxa). (Full 257).}

Després de realitzar la parada anterior, cal continuar I recorregut cap el poble de Beget, seguit la carretera local GiV - 5223. Per aquesta carretera, després de superar el Coll de Bestrecà i el trencall de Sant Miquel de la Pera (per l'esquerra), començarem baixar cap a la vall del Riu Llierca, per on es troba la població de Beget. En arribar-hi, farem una nova aturada, després de recórrer uns $6 \mathrm{Km}$ més, des de la parada anterior.

En aquest recorregut, hem anat trobant, per arreu, afloraments dels materials de l'Eocè Inferior - Paleocè. Aquests materials, en molt bona part pertanyen a l'llerdià. Es tracte d'afloraments de gresos, calcolutites, tot i que molt sovint Molt sovint, tenen un clar caràcter carbonatats, eminentment calcari.

Ara, en arribar a la vall del riu Llierca, després d'una llarga baixada, ens trobarem al poble de Beget. Part del poble es troba aturonat sobre uns afloraments carbonatats que pertanyen a la Formació Sagnari, de l'llerdià. (fotografia 7).

Per d'altra banda, per sobre del poble, es pot veure una cinglera, de caràcter carbonatat. Aquesta cinglera es troba constituïda per materials carbonatats, que també pertanyen a la Formació Sagnari, de I’Eocè Inferior - Paleocè, de I'llerdià.

Cal dir que tots aquests materials es troben plegats i replegats en envalcaments, formant part del Mantell del Cadí, del que ja n'hem parlat anteriorment, especialment en els recorreguts cap a les dues parades anteriors.

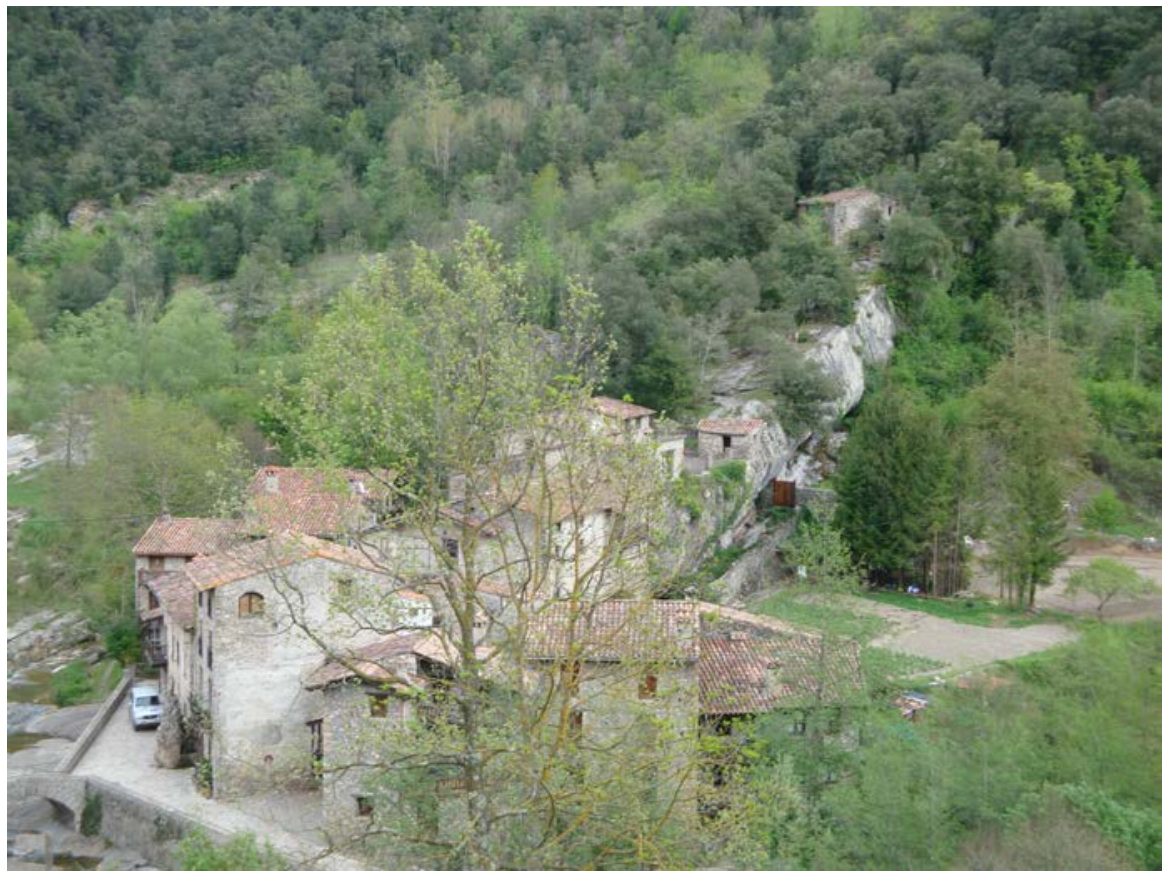

Fotografia 7. Cinglera de Beget. Terme d’Oix 


\subsection{Parada 8. ENTRADA A ROCABRUNA, (Rocabruna, terme municipal de Camprodon, comarca del Ripollès, Alta Garrotxa; antigament del terme de Beget, de la comarca de la Garrotxa). (Full 257).}

Després de realitzar l'aturada anterior, cal continuar el recorregut, anant ara cap el poblet de Rocabruna. Així, ens caldrà seguir per la carretera local GiV - 5223. En arribar al poble darrerament esmentat, ens caldrà fer una nova aturada. Així, des de l'anterior, haurem recorregut uns $6 \mathrm{Km}$, aproximadament.

En aquest recorregut, haurem anat trobant afloraments dels materials cenozoics del Paleocè i de I'Eocè Inferior. En bona part, haurem trobat nivells de calcolutites grises de l'llerdià. Més endavant, prop de Rocabruna, haurem trobat uns nivells carbonatats de I'Eocè Superior, les calcàries d Vallcebre (o calcàries "clar de Lluna).

Més endavant, quasi en sobrepassar el poble de Rocabruna, trobarem uns nivells rogencs de gresos i calcolutites, que pertanyen al Garumnià (fotografia 8).. Posteriorment, trobarem afloraments dels materials de l'Ordovicià. Aquests darrers materials ja pertanyen al Mantell del Cadí.

\subsection{Parada 9. MINES DE LES FERRERES DE ROCABRUNA, (Rocabruna, abans del terme de Beget a la comarca de la Garrotxa; i actualment del de Camprodon, comarca del Ripollès). (Full 218).}

En arribar a Rocabruna, ens caldrà agafar el camí que es dirigeix cap a les Mines de les Ferreres, tot fent una fillola. En arribar-hi, després d'un recorregut proper al $4 \mathrm{Km}$, ens caldrà fer una nova aturada, dintre del recorregut d'aquest itinerari.

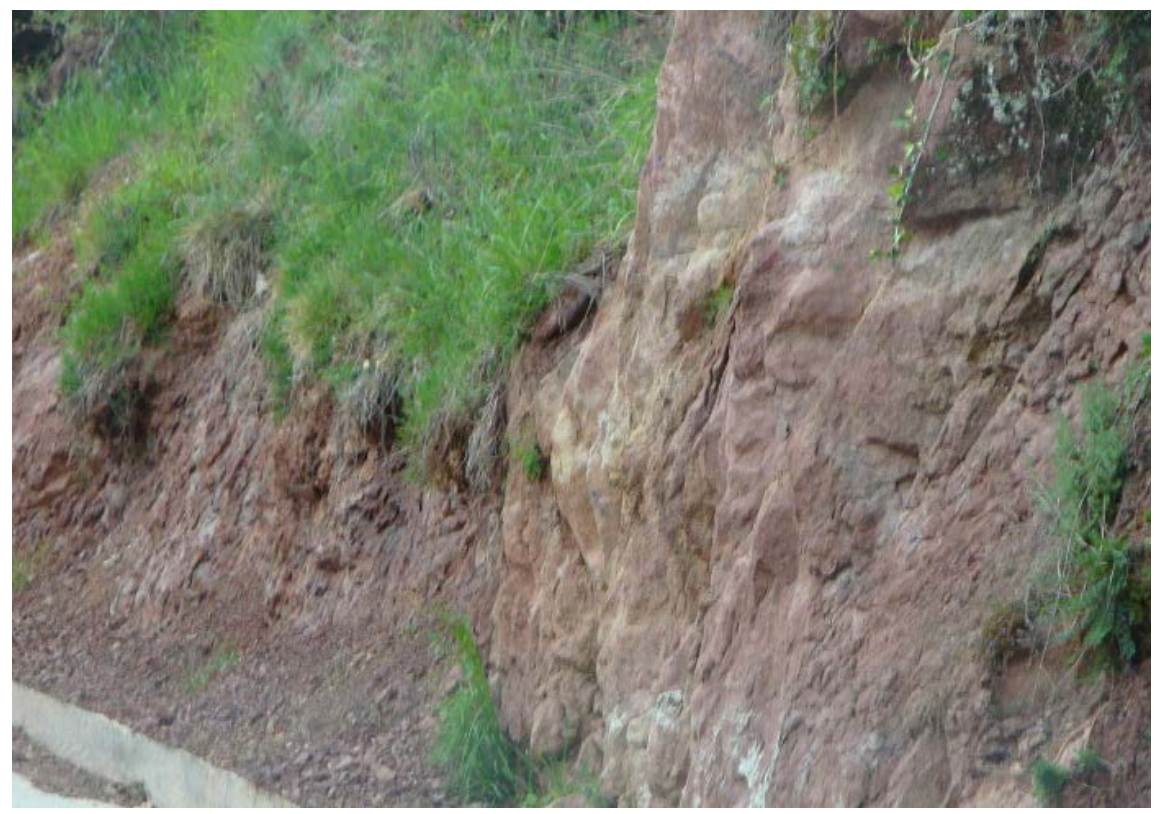

Fotografia 8. Aflorament dels materials del Garumnià. Rocabruna 
En bona part d'aquest recorregut, haurem trobat afloraments dels materials paleozoics de I'Ordovicià, situant-se dintre del Mantell del Cadí. Tot i així, prop de l'indret de I'aturada, trobarem de nou els materials rogencs del Garumnià (que ja hem vist a Rocabruna). Aquests material són discordants amb els anteriors, amb els de l'Ordovicià.

Pel que fa a les Mines de les Ferreres de Rocabruna, cal dir que es localitzen sobre mineralitzacions de rebliment de cavitats d'origen càrstic, les quals es troben localitzades sobre uns afloraments de nivells carbonatats de l'Ordovicià abans esmentats.

Per d'altra banda, com ja s'ha dit, aquests nivells es troben en contacte discordants amb altres materials, de caràcter detrític que els cobreixen, i que pertanyen al Garumnià, Uns i altres materials pertanyen al Mantell del Cadí, on ara ens trobem situats.

Entre els minerals primaris presents a l'indici, cal fer esment dels següents: CALCOPIRITA (abundant), ESTIBINA, GALENA, PIRITA, TENNANTITA, TETRAEDRITA (abundant), CALCITA, FLUORITA (indicis), BARITINA (molt abundant) i QUARS.

Per d'altra banda, entre els minerals d'alteració, cal fer esment dels següents: CALCOSINA, CERVANTINITA, ESTIBICONITA, GOETHITA (sempre terrosa i limonítica), HEMATITES (terròs), PIROLUSITA (dendrítica), ATZURITA, MALAQUITA i CALCANTITA.

De tots ells, els minerals més abundants són els de coure, en especial la calcopirita i els coures grisos) sobretot la tetraedrita; així com la baritina. També són molt abundants les alteracions dels minerals de coure, com és el cas dels dos carbonats d'aquest metall.

També cal dir, que prop d'on som es troba l'Encavalcament de Ribes, el qual posa en contacte els materials del Mantell del Cadí, amb els del Mantell del Canigó, situats al Nord d'on ara som.

\subsection{Parada 10 - CONDICIONAL CARRETERA DE ROCABRUNA A CAMPRODON, Km 2, (terme municipal de Molló, comarca del Ripollès). (Full 256).}

Després de fer l'aurada anterior, cal retornar cap a Rocabruna, desfent la fillola. Tot seguit, ens caldrà continuar cap a Camprodon, seguint la carretera local que es dirigeix cap aquest poble, la GiV -5223. En arribar al Km 2, farem una nova aturada, a uns $8 \mathrm{Km}$ de l'anterior parada.

En aquest recorregut en tornar a Rocabruna, haurem trobat de nou els materials rogencs del Garumnià. Ara, anant cap a Camprodon, trobarem afloraments paleozoics de I'Ordovicià. Tot i així, a l'indret de l'aturada, trobarem afloraments dels materials del Carbonífer. Per d'altra banda, en aquest tram hem circulat pel Mantell del Cadí, tot i que som molt a prop del Mantell del Canigó. (fotografia 9). 


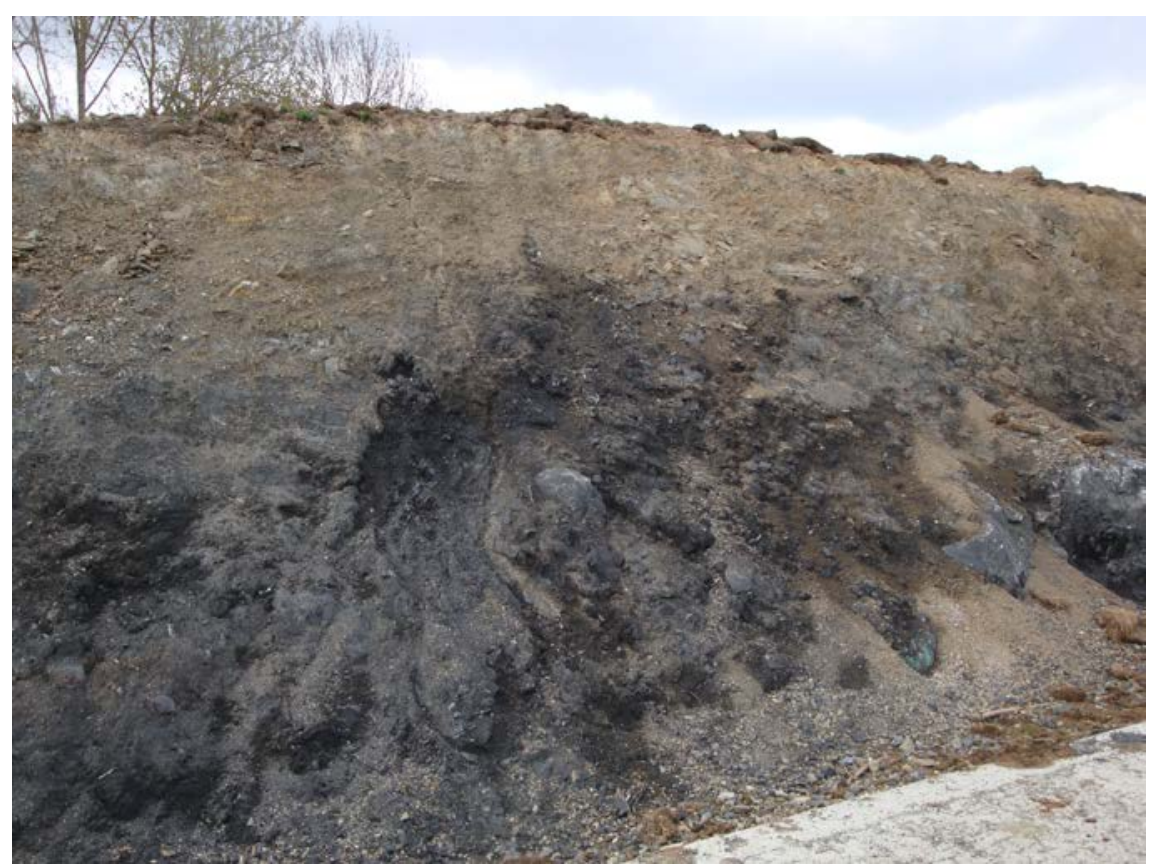

Fotografia 9. Aflorament dels materials del carbonífer. Terme de Molló

\subsection{Parada 11. VARIANT DE LA CARRETERA C-38, A LA POBLACIÓ DE CAMPRODON, (terme municipal de Camprodon, comarca del Ripollès). (Full 256).}

Després de realitzar la parada anterior, cal continuar per la carretera local GiV - 5223, fins arribar a la cruïlla amb la carretera autonòmica C -38. En trobar-la, ens caldrà anar cap a la propera població de Camprodon. En arribar-hi, seguirem per la circumval-lació. Poc després d'agafar-la, farem una nova aturada a l'esquerra de la carretera Així, des de la parada anterior, haurem recorregut uns $10 \mathrm{Km}$, per tal d'arribar fins aquí.

En aquest recorregut, hem sobrepassat I'Encavalcament de Ribes de Freser - Setcases, entrant breument al Mantell del Canigó (trobant afloraments dels nivells esquistosos de I'Ordovicià). Tot i això, hem tornat a sobrepassar l'encavalcament, trobant-nos ara dintre del Mantell del Cadí, entre afloraments dels nivells foscos del Carbonífer, els quals es troben formats per nivells esquistosos i grafitosos. FOTOGRAFI 10.

Aquests darrers, són precisament els materials que es troben a l'indret de l'aturada. Així, en aquest Iloc hi afloren els nivells esquistosos i grafitosos negres, que pertanyen al Carbonífer, i que es situen dintre del Mantell del Cadí. 


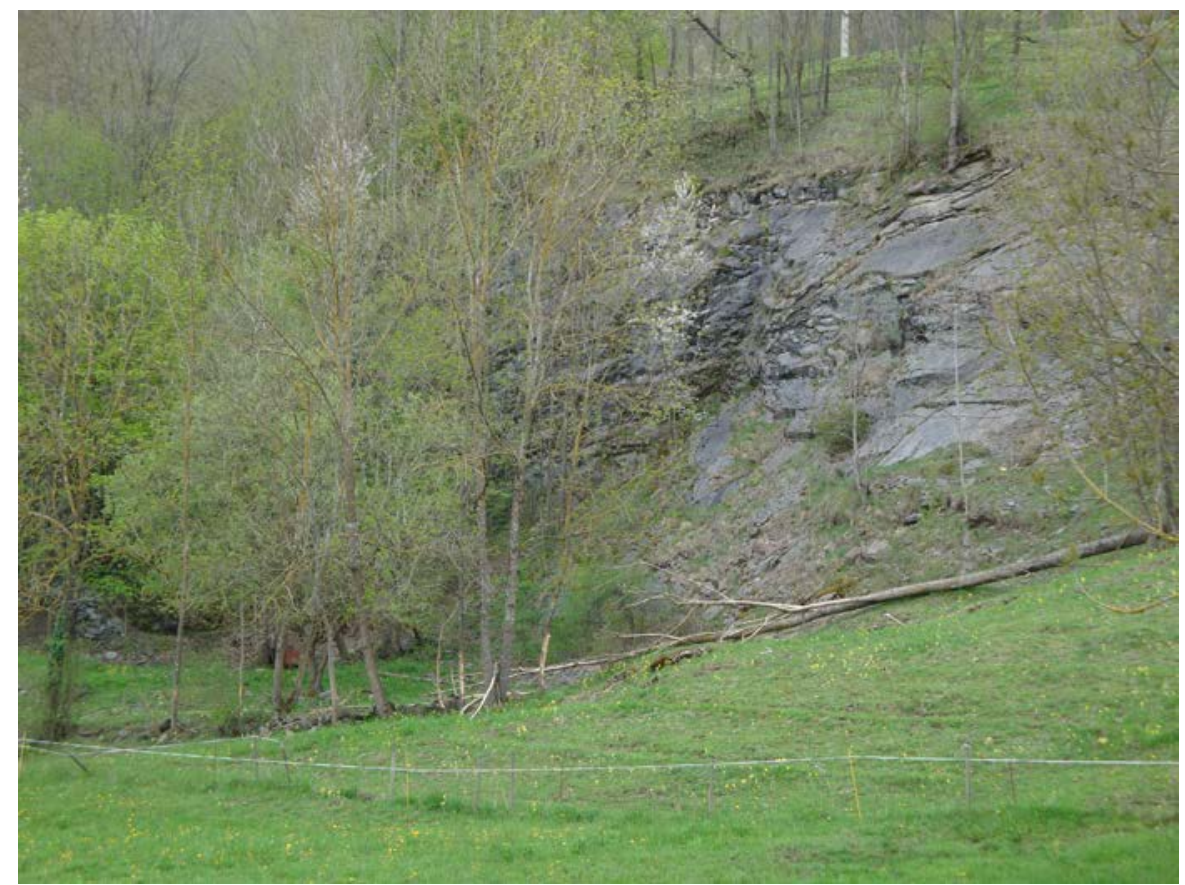

Fotografia 10. Aflorament dels materials del carbonífer a la variant de Camprodon

En aquest indret finalitza el recorregut de l'itinerari.

\section{Bibliografia}

BRGM (1936).- Carte Géologique de la France (1/80.000). Feuille 257 (Prades), 2eme Edition, Bureau Recher. Géolog. et Minières, Orleans, France

GUIMERÀ, J. et altri (1992).- Geologia (II), Història Natural dels Països Catalans, Vol. 2, 547 pag. Enciclopèdia catalana, S.A., Barcelona.

IGME (1991).- Mapa Geológico de España a escala 1:50.000 (sintesis de la cartografia existente). Full i memòria número 257 (Ripoll). Inst. Geol. Minero de España, Minist Indústria. Madrid.

MATA-PERELLÓ, J.M. (1991).- Els Minerals de Catalunya. Arxius de la Secció de Ciències, t. XCIII, 442 pag. Institut d’Estudis Catalans. Barcelona.

MATA-PERELLÓ, J.M (1996a).- Itinerari geològic-mineralògic per la comarca del Ripollès: a I'Abella, Setcases, Tragurà i a Molló, Inèdit, 7 pàgines. Manresa

MATA-PERELLÓ, J.M. (1997a).- Recerca Geològica i Mineralògica per les comarques del Ripollès i del Vallespir: des de Surroca a Mollo, per Costabona i Setcases. Inèdit, 10 pàgines. Manresa 
MATA-PERELLÓ, J.M. (1997b).- Recerca geològica i minera per les comarques del Ripollès, del Vallespir i del Rosselló: des de Molló a la Menera i a Bastida. Algeps, sèrie B, n1 59, 9 pàgines. Manresa

MATA-PERELLÓ, J. M. (1998a).- Recerca Geològica i Mineralògica per les comarques del Vallespir i del Ripollès: des de Costoja a l'Avetera, i des de la Menera a Rocabruna. Inèdit. 12 pàgines. Manresa

MATA-PERELLÓ, J. M. (1998b).- Recorregut de recerca geològica i mineralògica per les comarques del Ripollès i del Vallespir: des de Setcases al Pic de Costabona i a Rocabruna. Inèdit . 11 pag. Manresa

MATA-PERELLÓ, J. M. (2007).- Recorregut de recerca geològica i mineralògica per les comarques del Ripollès i del Vallespir: des de Setcases a Rocabruna i a Prats de Molló. Inèdit. 8 pag. Manresa

MATA-PERELLÓ, J. M. (2011).- Recorregut de recerca geològica i mineralògica per les comarques del Ripollès i del Vallespir: des de Camrodon a Rocabruna i a Prats de Molló. Inèdit. 7 pàgines. Manresa

MATA-PERELLÓ, J.M. i SANZ BALAGUÉ, J. (1993).- Guia de Identificación de Minerales, adaptada fundamentalmente a la Península Ibérica. Parcir, Edicions Selectes. 205 pàgines. Manresa

RIBA ARDERIU, O. Et altri. (1976).- Geografia Fisica dels Països Catalans. Edit. Ketres, 254 pàgines. Barcelona

SGC (1990).- Mapa Geològic de Catalunya a escala 1:250.000, Servei Geològic de Catalunya (Inst. Cartograf. de Catalunya). Barcelona 